АКТУАЛЬНІ ПИТАННЯ ЮРИДИЧНОЇ НАУКИ

УДК 346.1

DOI https://doi.org/10.32844/2618-1258.2019.6.60

КОМАРНИЦЬКИЙ Д.С.

\title{
ХАРАКТЕРИСТИКА ЕКОНОМІКО-ПРАВОВОГО ЗМІСТУ ЕКСПОРТНОЇ ДІЯЛЬНОСТІ ЯК ПРЕДМЕТА ПРАВОВОГО РЕГУЛЮВАННЯ
}

У даній статті досліджується економіко-правовий зміст суспільних відносин у сфері експортної діяльності. Зроблено висновок про те, що експортна діяльність, як предмет правового регулювання, має складний комплексний міжгалузевий характер і підлягає регулюванню нормами національного, міжнародного приватного та міжнародного публічного права.

Ключові слова: предмет правового регулювання, міжнародне економічне співробітництво, зовнішньоекономічна діяльність, експортна діяльність, експорт.

В данной статье исследуется экономико-правовое содержание общественных отношений в сфере экспортной деятельности. Сделан вывод о том, что экспортная деятельность, как предмет правового регулирования, имеет сложный комплексный межотраслевой характер и подлежит регулированию нормами национального, международного частного и международного публичного права.

Ключевые слова: предмет правового регулирования, международное экономическое сотрудничество, внешнеэкономическая деятельность, экспортная деятельность, экспорт.

This article explores the economic and legal content of public relations in the sphere of export activities. It has been concluded that export activity, as a subject of legal regulation, has a complex cross-sectoral character and is subject to regulation by the rules of national, international private and international public law.

Key words: subject of legal regulation, international economic cooperation, foreign economic activity, export activity, export.

Постановка проблеми. Дослідження економіко-правового змісту суспільних відносин у сфері експортної діяльності як предмета правового регулювання зумовлене необхідністю удосконалення механізму, форм та методів державного регулювання у цій сфері, створення належних організаційних, економічних та правових умов для збільшення обсягів експорту товарів (робіт, послуг) українського походження. Державна підтримка експортної діяльності є одним із пріоритетів як внутрішньої, так і зовнішньої політики України.

Аналіз останніх досліджень і публікацій. Правове регулювання зовнішньоекономічної діяльності вже досліджувалося у вітчизняній юридичній науці $[1,2]$. Однак дослідження економіко-правового змісту суспільних відносин у сфері експортної діяльності як предмета правового регулювання потребують подальшого розвитку з огляду на їх актуальність для реалізації державної політики щодо підтримки та стимулювання експорту в Україні.

Постановка завдання. Завданням даної статті $€$ характеристика економіко-правового змісту експортної діяльності як предмета правового регулювання.

(с) КОМАРНИЦьКИЙ Д.С. - аспірант (ДВНЗ «Київський національний економічний університет імені Вадима Гетьмана») 
Основні результати дослідження. Суспільні правовідносини виникають у процесі застосування права до тих чи інших суспільних відносин і $є$ юридичним зв'язком між учасниками суспільних відносин, який регулюється нормами права і характеризується наявністю прав та обов'язків. Регулюючий вплив права на суспільні відносини полягає в тому, що воно в своїх нормах створює модель обов'язкової або дозволеної поведінки різних учасників цих відносин. Правове регулювання - це дія права на суспільні відносини за допомогою певних юридичних засобів, перш за все норм права. Предмет правового регулювання - це найбільш важливі для держави, фізичних і юридичних осіб суспільні відносини, що потребують правового регулювання і об'єктивно піддаються йому, сторонами яких виступають свідомі і вольові учасники, які є правоздатними і дієздатними особами [3, с. 209; 4, с. 50; 5, с. 622-624; 6, с. 794].

Характеризуючи суспільні правовідносини у сфері експортної діяльності необхідно дослідити склад цих правовідносин, тобто їх економіко-правовий зміст, суб'єктний склад та об'єкти.

Національні економіки взаємодіють через міжнародні економічні відносини, які являють собою систему економічних зв'язків з приводу виробництва, розподілу, обміну та споживання, що вийшли за межі національних господарств. В основі міжнародних економічних відносин лежить міжнародний поділ праці, що являє собою обмін між країнами факторами і результатами виробництва у певних кількісних і якісних співвідношеннях. Суб'єктами міжнародних економічних відносин $\epsilon$ фізичні особи, юридичні особи, держави та міжнародні організації. Формами міжнародних економічних відносин $є$ міжнародна торгівля, міжнародний рух капіталу та міжнародна міграція робочої сили [7, с. 29,38$]$.

Міжнародна економічна діяльність України становить неоднорідний та багатоаспектний предмет дослідження. Ї̈̈ слід розглядати в контексті національних інтересів як в регіональному, так і в глобальному масштабах. Порівнюючи терміни «міжнародна економічна діяльність» i «зовнішньоекономічна діяльність» в економічній науці зроблено висновок про те, що термін «міжнародна економічна діяльність» $є$ ширшим і охоплює не тільки власне сферу виробничої, торгівельної діяльності, ті міжнародні за характером економічні дії, які спрямовані на отримання та збільшення прибутку, а поширюється також на непідприємницькі регулятивні за характером діiі, на інструменти впливу з метою поліпшення загальних умов господарювання як з боку національних урядів, так і з боку міжнародних організацій та структур. Міжнародна економічна діяльність $€$ цілісною системою господарських зв'язків між національними економіками різних країн, належних до них або утворених ними суб'єктами господарського життя, а також міжнародними організаціями, яка має характерні лише для себе взаємозв'язки, закономірності та реалізує ті специфічні інтереси, які пов'язані з використанням переваг міжнародного співробітництва, поділу праці та факторного розміщення [8, с. 20-25].

В наукових джерелах міжнародного приватного права зазначається, що постійне зростання частки правових питань міжнародної торгівлі, питань врегулювання економічного співробітництва у міжнародному публічному праві стало причиною формування міжнародного економічного права. Але регульовані ним відносини мають не цивільно-правовий, а публічно-правовий, міждержавний характер. Що ж стосується міжнародного приватного права, то ним регулюється група цивільно-правових відносин, що мають міжнародний характер [9, с. 5-15].

У науці міжнародного публічного права існує концепція, згідно із якою міжнародні економічні

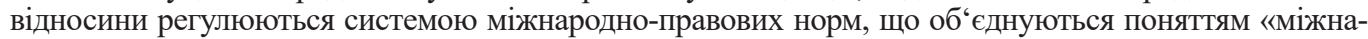
родне економічне право» $[10$, с. 235,236$]$. Міжнародні економічні відносини є складовою частиною системи міжнародних відносин, особливою формою суспільно-виробничих зв'язків між окремими державами та міжнародними організаціями, між міжнародними організаціями [11, с. 12; 12, с. 5-15].

Експорт та імпорт товарів, капіталів та робочої сили є одним із видів зовнішньоекономічної діяльності. Експортна діяльність має складний комплексний міжгалузевий характер і підлягає регулюванню нормами національного, міжнародного публічного та міжнародного приватного права.

Експортна діяльність, як один із видів зовнішньоекономічної діяльності, відноситься до видів господарської діяльності.

Згідно із ч. 1 ст. 3 Господарського кодексу України під господарською діяльністю розуміється діяльність суб'єктів господарювання у сфері суспільного виробництва, спрямована на виготовлення та реалізацію продукції, виконання робіт чи надання послуг вартісного характеру, що мають цінову визначеність [13].

У ст. 1 Закону України «Про зовнішньоекономічну діяльність» зазначається, що господарська діяльність - це будь-яка діяльність, у тому числі підприємницька, пов'язана з виробництвом і обміном матеріальних та нематеріальних благ, що виступають у формі товару [14]. 
Відповідно до п. 14.1.36 Податкового кодексу України господарська діяльність - це діяльність особи, що пов'язана з виробництвом (виготовленням) та/або реалізацією товарів, виконанням робіт, наданням послуг, спрямована на отримання доходу і проводиться такою особою самостійно та/або через свої відокремлені підрозділи, а також через будь-яку іншу особу, що діє на користь першої особи, зокрема за договорами комісії, доручення та агентськими договорами [15].

Згідно із абз. 4 ст. 1 Закону України «Про ліцензування певних видів господарської діяльності» господарська діяльність - це будь-яка діяльність, у тому числі підприємницька, юридичних осіб, а також фізичних осіб - суб'єктів підприємницької діяльності, пов'язана з виробництвом (виготовленням) продукції, торгівлею, наданням послуг, виконанням робіт [16].

Відповідно до ч. 1 ст. 377 Господарського кодексу України зовнішньоекономічною діяльністю суб’єктів господарювання є господарська діяльність, яка в процесі іiї здійснення потребує перетинання митного кордону України майном та/або робочою силою [13].

У ст. 1 Закону України «Про зовнішньоекономічну діяльність» зазначається, що зовнішньоекономічна діяльність - це діяльність суб'єктів господарської діяльності України та іноземних суб'єктів господарської діяльності, побудована на взаємовідносинах між ними, що має місце як на території України, так і за ії межами [14].

Згідно із ст. 378 Господарського кодексу України суб'єктами зовнішньоекономічної діяльності є: 1) господарські організації - юридичні особи, створені відповідно до Цивільного кодексу України, державні, комунальні та інші підприємства, створені відповідно до Господарського кодексу України, а також інші юридичні особи, які здійснюють господарську діяльність та зареєстровані в установленому законом порядку; 2) громадяни України, іноземці та особи без громадянства, які здійснюють господарську діяльність та зареєстровані відповідно до закону як підприємці; 3) зовнішньоекономічні організації, що мають статус юридичної особи, утворені в Україні відповідно до закону органами державної влади або органами місцевого самоврядування [13].

Відповідно до ч. 1 ст. 3 Закону України «Про зовнішньоекономічну діяльність» суб'єктами зовнішньоекономічної діяльності в Україні можуть бути: фізичні особи - громадяни України, іноземні громадяни та особи без громадянства, які мають цивільну правоздатність і дієздатність згідно з законами України і постійно проживають на території України; юридичні особи, зареєстровані як такі в Україні і які мають постійне місцезнаходження на території України, у тому числі юридичні особи, майно та/або капітал яких є повністю у власності іноземних суб'єктів господарської діяльності; об'єднання фізичних, юридичних, фізичних і юридичних осіб, які не $\epsilon$ юридичними особами згідно з законами України, але які мають постійне місцезнаходження на території України і яким цивільно-правовими законами України не заборонено здійснювати господарську діяльність; структурні одиниці іноземних суб'єктів господарської діяльності, які не $\epsilon$ юридичними особами згідно з законами України (філії, відділення, тощо), але мають постійне місцезнаходження на території України; спільні підприємства за участю суб'єктів господарської діяльності України та іноземних суб'єктів господарської діяльності, зареєстровані як такі в Україні і які мають постійне місцезнаходження на території України; інші суб'єкти господарської діяльності, передбачені законами України [14].

Усі суб’єкти зовнішньоекономічної діяльності мають право на здійснення будь-яких видів зовнішньоекономічної діяльності і зовнішньоекономічних операцій, якщо інше не встановлено законом. Види зовнішньоекономічної діяльності, перелік зовнішньоекономічних операцій, що здійснюються на території України, умови та порядок їх здійснення суб'єктами зовнішньоекономічної діяльності, а також перелік товарів (робіт, послуг), заборонених для експорту та імпорту, визначаються законом (ст. 379 Господарського кодексу України) [13].

Перелік видів зовнішньоекономічної діяльності міститься у ст. 4 Закону України «Про зовнішньоекономічну діяльність». Їх можна об'єднати по таким напрямкам, як експорт та імпорт товарів, послуг, капіталів та робочої сили; наукова, виробнича, освітня та інша кооперація; міжнародні фінансові, кредитні та розрахункові операції; створення юридичних осіб та представництв за межами України та створення іноземними суб'єктами господарської діяльності юридичних осіб та представництв на території України; спільна підприємницька діяльність; діяльність з обігу нематеріальних об'єктів власності; організація та здійснення діяльності в галузі проведення виставок, аукціонів, торгів, конференцій, симпозіумів, семінарів та інших подібних заходів; орендні, у тому числі лізингові, операції, тощо. Слід зазначити, що наведений у ст. 4 даного закону перелік видів зовнішньоекономічної діяльності не є вичерпним, і дозволяється здійснювати інші види зовнішньоекономічної діяльності, що не заборонені прямо і у виключній формі законами України [14]. 
За енциклопедичним визначенням експорт (англ. export - вивіз, від лат. exportare - вивозити) - це вивезення товарів, послуг, технологій та ін. з митної території країни за кордон [17].

Згідно нормативного визначення експорту, що міститься у ст. 1 Закону України «Про зовнішньоекономічну діяльність», експорт (експорт товарів) - це продаж товарів українськими суб' єктами зовнішньоекономічної діяльності іноземним суб' єктам господарської діяльності (у тому числі з оплатою в негрошовій формі) з вивезенням або без вивезення цих товарів через митний кордон України, включаючи реекспорт товарів. При цьому термін реекспорт (реекспорт товарів) означає продаж іноземним суб'єктам господарської діяльності та вивезення за межі України товарів, що були раніше імпортовані на територію України [14].

Основи правового регулювання господарської комерційної діяльності (підприємництва) містяться у главі 4 Господарського кодексу України, а некомерційної господарської діяльності - у главі 5 зазначеного кодексу. Оскільки експортна діяльність $є$ видом господарської діяльності, то вона теж може бути як комерційною, так і некомерційною.

Господарська діяльність має такі загальні ознаки: а) здійснюється у сфері суспільного виробництва (а не у сфері особистого споживання); б) перебуваючи у сфері суспільного виробництва, ця діяльність базується на ринкових засадах і спрямована на задоволення приватних інтересів суб'єктів господарювання за умови дотримання ними публічних інтересів; в) господарська діяльність перш за все пов'язана із тією стороною суспільного виробництва, у якій здійснюється господарське використання майна; г) вона є діяльністю, що організує виробництво та використання майна; д) результати господарської діяльності мають вартісний характер [18, с. 12].

Спеціальними ознаками зовнішньоекономічної діяльності в науці господарського права визначаються: 1) за своєю сутністю вона $є$ господарською діяльністю, спрямованою на виготовлення та реалізацію продукції, виконання робіт чи надання послуг вартісного характеру, що мають цінову визначеність; 2) здійснюється визначеним в законодавчому порядку колом суб'єктів; 3) обов'язковою умовою віднесення того чи іншого виду діяльності до зовнішньоекономічної $\epsilon$ перетин митного кордону України майном чи робочою силою. [18, с. 573].

Однак слід зазначити, що перетин митного кордону майном чи робочою силою не $\epsilon$ обов'язковою ознакою зовнішньоекономічної діяльності в цілому, про що йдеться у ч. 1 ст. 377 Господарського кодексу України. Перетин митного кордону можливий лише товарами або транспортними засобами при здійсненні експортно-імпортних операцій, а при міжнародному співробітництві у сфері обміну робочою силою - такою робочою силою. Здійснення всіх інших видів зовнішньоекономічної діяльності, передбачених ст. 4 Закону України «Про зовнішньоекономічну діяльність», не у всіх випадках вимагає перетину кордону товарами чи робочою силою.

Дослідивши економічний та правовий зміст експортної діяльності можна зробити висновок про те, що експортна діяльність має наступні правові ознаки: це суспільні відносини в торгівельній (обмін товарами, роботами, послугами), інвестиційній, валютно-фінансовій, виробничо-промисловій та науково-технічній сферах; зазначені відносини мають господарський характер; суб'єктами експортної діяльності є суб'єкти господарської діяльності України та іноземні суб'єкти господарської діяльності; має місце як на території України, так і за її межами; може бути побудована на підприємницьких або непідприємницьких засадах; врегульована нормами національного законодавства країн походження ії суб'єктів, а також нормами міжнародного приватного та міжнародного публічного права.

Висновки і перспективи подальших досліджень. Експорт товарів, робіт, послуг, капіталів та робочої сили є одним із видів зовнішньоекономічної діяльності. Експортна діяльність, як предмет правового регулювання, має складний комплексний міжгалузевий характер і підлягає регулюванню нормами національного, міжнародного приватного та міжнародного публічного права. Як вид зовнішньоекономічної діяльності, експортна діяльність є видом господарської діяльності. Перспективи подальших досліджень економіко-правового змісту суспільних відносин у сфері експортної діяльності як предмета правового регулювання зумовлені необхідністю удосконалення механізму, форм та методів державного регулювання у сфері зовнішньоекономічної діяльності в Україні та ії міжнародного економічного співробітництва.

\section{Список використаних джерел}

1. Поєдинок В. В. Правове регулювання зовнішньоекономічної діяльності : навч. посіб. К.: Юрінком Інтер, 2006. 288 с.

2. Омельченко А. В. Адміністративно-правові засади зовнішньоекономічної діяльності в Україні : монографія. К.: КНЕУ, 2011. 309 с. 
3. Алексеев С.С. Теория права [2-е изд., перераб. и доп.]. М.: БЕК, 1995. 320 с.

4. Правознавство : підручник / [Опришко В.Ф., Шульженко Ф.П. та ін.] ; за заг. ред. В.Ф. Опришка, Ф.П. Шульженка. К.: КНЕУ, 2003. 767 с.

5. Теория государства и права : курс лекций / [под ред. Н.И. Матузова, А.В. Малько]. М.: Юристь, 1997. 672 с. $836 \mathrm{c}$.

6. Теория государства и права : учебник / [под. ред. М.Н. Марченко]. М.: Зерцало, 2009.

7. Пахомов Ю.М. Національні економіки в глобальному конкурентному середовищі / Пахомов Ю.М., Лук’яненко Д.Г., Губський Б.В. К.: Україна, 1997. 237 с. 2003. $948 \mathrm{c}$.

8. Новицький В.Є. Міжнародна економічна діяльність України : [підручник]. К.: КНЕУ,

9. Богуславский М.М. Международное частное право : [учебник] [2-е изд., перераб. и доп.]. М.: Междунар. отношения, 1994. 416 с.

10. Міжнародне право : навч. посібник / [за ред. М.В. Буроменського]. К.: Юрінком Інтер, 2006. $336 \mathrm{c}$.

11. Міжнародне економічне право : підручник / [Опришко В., Коста А., Квінтано К. та ін.] ; за наук. ред. В. Опришка. К.: КНЕУ, 2006. 311 с.

12. Опришко В.Ф. До питання про предмет та джерела міжнародного економічного права. Правове регулювання економіки : зб. наук. праць. К.: КНЕУ, 2005. Вип. 5. С. 5 - 15.

13. Господарський кодекс України : Закон України від 16.01.2003 р. Відомості Верховної Ради України. 2003. № 18; № 19-20; № 21-22. Ст. 144.

14. Про зовнішньоекономічну діяльність : Закон України від 16.04.1991 р. № 959-XII. Biдомості Верховної Ради УРСР. 1991. № 29. Ст. 377.

15. Податковий кодекс України : Закон України від 08.04.2011 р. Відомості Верховної Ради України. 2011. № 13-14, № 15-16, № 17. Ст. 112.

16. Про ліцензування певних видів господарської діяльності : Закон України від 01.06.2000 p. № 1775-III. Відомості Верховної Ради України. 2000. № 36. Ст. 299.

17. Юридична енциклопедія : в 6 т. / [редкол.: Ю.С. Шемшученко (голова) та ін.]. К.: Видво «Українська енциклопедія» імені М. П. Бажана, 1998-2004. Т. 2: Д-Й. 1999. 744 с.

18. Науково-практичний коментар Господарського кодексу України / [Знаменський Г. Л., Хахулін В. В., Щербина В. С. та ін.] ; за заг. ред. В.К. Мамутова. К.: Юрінком Інтер, 2004. 688 с. 